\title{
Diante do abismo digital: mídia-educação e mediações culturais
}

\author{
Monica Fantin*
}

Gilka Girardello**

\section{Resumo:}

Este artigo discute a inclusão digital na perspectiva da educação e da cultura, com destaque para as formas como a questão se apresenta no Brasil, mas entendendo que elas não são exclusivas desse contexto. Diante dos complexos desafios à inclusão digital no contexto da globalização, o artigo enfatiza a importância de que as crianças e os jovens possam se apropriar de forma significativa das novas tecnologias e linguagens, numa perspectiva de que a inclusão significa muito mais do que o acesso às tecnologias, configurando-se em uma das frentes de luta contra a desigualdade. As autoras propõem que o enfrentamento da barreira digital seja enriquecido com a valorização das mediações culturais. Nesse sentido, discutem as possibilidades de uma abordagem culturalista de mídia-educação para promover uma inclusão digital que seja experiência de cidadania, pertencimento e participação crítica e criativa na cultura.

Palavras-chave: Inclusão digital. Mídia. Cidadania. Educação. Inovações tecnológicas.

\footnotetext{
Doutora em Educação pelo Programa de Pós-Graduação em Educação da UFSC. Professora do Centro de Ciências de Educação da Universidade Federal de Santa Catarina.

** Doutora em Comunicação pela Escola de Comunicações e Artes - USP. Professora do Centro de Ciências de Educação da Universidade Federal de Santa Catarina.
} 
Nos primórdios da popularização dos microcomputadores, nos anos de 1980, muito se falava do potencial infinito da infovia da informação que prometia comunicação igualitária e multidirecional entre pessoas, grupos e nações. Outra metáfora, porém, não demorou a surgir, fazendo a crítica ao otimismo ingênuo dos primeiros anos: a da barreira digital. Como poderíamos superar o abismo que separa os alfabetizados digitais daqueles excluídos das promessas tecnológicas? Hoje nos perguntamos: que outra imagem poderia representar de forma alternativa essa tensão, não como obstrução e sim como um espaço a ser atravessado? Um rio, que tanto separa quanto une? Um mar de múltiplas correntes que, ao mesmo tempo, divergem e convergem? Como cruzar esse rio, navegar esse mar?

Propomo-nos a discutir esse problema - a distância entre os que têm e os que não têm completo acesso aos arquivos da cultura disponibilizados pelas mídias e às possibilidades de recriá-los criticamente. Nosso foco são as novas configurações da questão diante da intensificação da presença das tecnologias digitais na educação e na cultura. Nossa discussão busca identificar possíveis contribuições aos dilemas da mídia-educação e da alfabetização digital que emergem do cenário brasileiro - um país de dimensões continentais onde a pulsação da mídia globalizada convive com uma forte cultura popular, frequentemente iletrada, muitas vezes na mesma cidade e a poucas quadras de distância uma da outra. Nossa ancoragem nos problemas tal como se apresentam no Brasil não significa, porém, que os vejamos como exclusivos do contexto brasileiro ou latino-americano.

A diversidade de práticas e deslocamentos semióticos resultante das formas como a indústria cultural foi incorporada nos contextos locais vem há muitas décadas desafiando os pensadores brasileiros. Conceitos como antropofagia e sincretismo cultural marcaram a crítica sociológica, antropológica e literária no século passado, na procura de compreender as tensões entre imagens e narrativas "locais" e "globais", tensões essas às vezes geradoras e às vezes paralisadoras. A proposta freireana de uma pedagogia de libertação, com sua ênfase em metodologias dialógicas que abrissem espaço à crítica radical e micropolítica da opressão, continua a inspirar um grande número de experiências educacionais, dentro e fora das escolas, ainda que nem sempre de forma explícita.

Este artigo identifica determinados temas e conceitos teóricos que têm instigado e desafiado o campo da mídia-educação em nosso país. O 
abismo digital é entendido na contradição entre exclusão e inclusão digital, sendo que, como veremos, nem sempre uma é o oposto da outra. Nos concentraremos em ideias associadas a práticas que tentam promover uma inclusão digital capaz de transcender limites utilitários e o acesso meramente operacional às máquinas e aos programas. Ou seja: uma inclusão que seja também política, social e cultural.

\section{Pensar a inclusão digital a partir da educação e da cultura}

A exclusão digital não é ficar sem computador ou telefone celular. É continuarmos incapazes de pensar, de criar e de organizar novas formas, mais justas e dinâmicas, de produção e distribuição de riqueza simbólica e material. (SCHWARTZ, 2000).

Quando se fala em inclusão digital, a ideia mais imediata tende a remeter à ampliação do acesso às máquinas. Uma outra forma de pensar a questão, porém, valoriza justamente aquilo que resiste a ser feito com as máquinas, o que tende a ficar fora da racionalidade tecnológica. Para nós, latino-americanos, as novas tecnologias de comunicação, ao levarem a simulação ao extremo, "fazem visível o resto não digerível, não simulável, que desde a alteridade cultural resiste à homogeneização generalizada." (MARTÍN-BARBERO, 2004, p. 183). Para Martín-Barbero, esse "resto" que resiste à diluição midiática tem relação com a existência das culturas populares, expressão que em nosso continente designa não o universo pop ou o do museu, mas um espaço de trocas e tensões simbólicas ainda muito vivas na sociedade.

Nessa linha, muitos autores em nosso contexto destacam a importância da resistência ao modelo de aceleração tecnológica e econômica dominante na sociedade ocidental contemporânea "que parece condenar todas as outras sociedades à integração ao seu paradigma ou ao desaparecimento", como diz Santos (2003, p. 28). Ele acrescenta que a resistência a esse modelo passa pela manutenção da diversidade de culturas e de sociedades, particularmente da "diversidade de temporalidades e de ritmos que não se aniquilam diante do imperativo da aceleração total.” (SANTOS, 2003, p. 28).

Assim, um primeiro pressuposto deste trabalho é a necessidade de pensarmos o acesso à cultura digital de forma dialética, deixando de 
lado qualquer iluminismo ingênuo ou perspectivas assistencialistas de distribuição de equipamentos. Buscaremos nos afastar também da lógica da integração globalizada e da dicotomia entre atraso e modernidade que impele populações inteiras à corrida pelos gadgets eletrônicos de cada temporada. Examinar a inclusão digital em países ditos periféricos exige atenção às manifestações culturais que correm por fora do ciberespaço, entendendo essa ausência não necessariamente como atraso, pobreza simbólica ou incompetência, mas sim como diferença valiosa e eloquente, possível lugar de constituição crítica. Exige ainda atenção às políticas públicas de formação de educadores, assim como a programas especiais de educação e cultura. Consideramos importante termos essa perspectiva cultural como horizonte para assegurar que a democratização do acesso digital signifique a ampliação da participação dos variados setores da população e não apenas uma forma nova de aproximação a velhos modos de discriminação e dominação.

Diversos estudos recentes abordam o impacto da exclusão digital na desigualdade social e na qualidade de vida. Esses estudos muitas vezes usam conceitos de exclusão digital que sugerem significados diferentes, o que gera problemas de compreensão. Embora seja corrente o uso da expressão "exclusão digital" em referência à falta de acesso à Internet, sabemos que a expressão não pode estar dissociada da relação com outras tecnologias de comunicação, dadas a complementaridade e convergência entre elas. A luta contra a exclusão digital, afinal, é só uma das dimensões da luta contra a pobreza e a desigualdade social. Nos Estados Unidos, por exemplo, a universalização do acesso à Internet nos últimos anos não diminuiu a desigualdade social, pelo contrário, como nota Sorj (2003).

Pensar dialeticamente a inclusão digital na América Latina requer além disso um olhar cuidadoso para a relação entre a educação e os meios audiovisuais. É mais uma vez Martín-Barbero (2004, p. 350) quem aponta que a escola empurra os jovens para a marginalização sociocultural quando se pauta ainda por passividade, redundância, uniformidade, anacronia e provincianismo que tanto contrastam com a atividade, a diversidade, a curiosidade, a atualidade e a abertura de fronteiras que marcam o mundo da comunicação (MARTÍN-BARBERO, 2004, p. 350). A consequência mais grave desse descompasso, diz o autor, é que as populações mais pobres ficam privadas da força da oralidade de sua cultura original na escola, ao mesmo tempo que não são introduzidas às gramáticas das novas mídias: "Quando 
é por aí, na cumplicidade/compenetração entre essas duas culturas - oral e visual - que passa a especificidade da experiência coletiva da modernidade na América Latina" (MARTÍN-BARBERO, 2004, p. 351).

A convivência, seja tensa ou cúmplice, mas sempre produtiva, entre diferentes culturas e imaginários na América Latina, tem sido objeto de análise de uma longa tradição crítica, justamente por ser uma marca das mais vigorosas na expressão artística e literária do continente. Para citar apenas dois exemplos, podemos começar pela bandeira da "antropofagia" levantada pelas vanguardas modernistas brasileiras da década de 1920: "Tupi, or not tupi, that is the question. Só me interessa o que não é meu”, dizia Oswald de Andrade no célebre Manifesto Antropófago, de 1928, pontuado por referências nacionalistas à alegria e ao potencial criador do sincretismo cultural. Uma segunda referência igualmente importante é o conceito de “culturas híbridas" desenvolvido pelo argentino García Canclini, de grande circulação acadêmica a partir da década de 1990 em todo o continente sul-americano. Com base nesse conceito, o autor discute os usos novos e originais que cada comunidade local faz de videogames, videocassetes, copiadoras xerox, valorizando a vitalidade igualitária dos mix singulares entre o culto, o popular e o massivo que as tecnologias favorecem.

Esses cruzamentos permitem a relativização dos fundamentalismos "religiosos, políticos, nacionais, étnicos, artísticos que absolutizam certos patrimônios e discriminam os demais”, diz Garcia Canclini (1998, p. 307). Quanto à educação, a relação fragmentária com os textos, os livros, anotações, pode também, sugere ele, induzir a "vínculos mais fluidos entre os textos, entre os estudantes e o Saber.” (GARCÍA CANCLINI, 1998, p. 308). Ao lado desses aspectos interessantes, porém, ele aponta para a desigualdade no capital cultural e na consequente diferença entre os sentidos das tecnologias construídos pelos jovens em contextos sociais diversos: a apropriação das tecnologias não é igual para "os adolescentes populares que vão às casas públicas de videogames e para os de classe média e alta que os têm em suas casas." (GARCÍA CANCLINI, 1998, p. 308). Além disso, grandes setores da sociedade brasileira passaram da cultura oral tradicional diretamente para a cultura audiovisual, ou, como preferem alguns autores, para a oralidade midiática, sem passar pela cultura escrita. É evidente que isso interfere na forma como nos relacionamos com os novos produtos midiáticos, já que os sentidos das tecnologias dependem das formas como 
se inserem no cotidiano, como a cultura se apropria delas e com base nelas se transforma.

Pensar dialeticamente a inclusão digital na América Latina exige ainda uma atenção às relações entre a educação e as culturas populares. No Brasil, existe ainda bem viva uma grande variedade de manifestações ligadas às diferentes tradições: dramas e rituais festivos e/ou religiosos, repertórios musicais, narrativos e poéticos acessíveis com relativa facilidade, mesmo em centros urbanos. Azevedo diz, a esse respeito, que

Se para os alunos das classes médias e altas, filhos e netos de pessoas alfabetizadas, o discurso da escola parece fazer sentido, para os alunos oriundos da tradição oral - a grande massa da população brasileira, ele apresenta um caráter autoritário, preconceituoso, discriminatório e excludente. (AZEVEDO, 2006).

O preconceito da escola contra a cultura oral tradicional, acrescenta o autor, faz com que muitas crianças fiquem sem referência, entre o desprezo institucional ao conhecimento e aos valores de seus parentes e com dificuldade de se identificarem com a "verdade" escolar. O resultado, podemos dizer, fecha o círculo da marginalização sociocultural a que nos referimos antes.

Uma reflexão que situa clara e criticamente a relação entre a educação e a exclusão social no país é feita por Muniz Sodré. Ele começa por lembrar que educamos não apenas para o viável de hoje, mas para o possível de amanhã. "Educar-se significa tomar distância (ética) da condição animal e preparar-se para a cidadania plena, que pressupõe o conhecimento pelo sujeito, além da instrumentação técnico-operativa, dos processos políticos e administrativos de sua Polis, isto é, de sua Cidade Humana" (SODRÉ, 2002, p. 87). A mudança do paradigma dominante e as novas formas de organização do trabalho provocam alterações na relação pedagógica em diversos níveis de escolaridade, nos modos de ensinar e aprender e nos conteúdos disciplinares. Mas na nova ordem sociocultural, explica ele, o conhecimento comum ou o saber sobre si entra em crise. A transmissão das informações no espaço midiático passa a caracterizar-se como persuasão ou fascinação, e desse fascínio com as maravilhas midiáticas pode decorrer uma prática ideológica que atribui à inovação tecnológica em si mesma 
um "poder mágico de solução dos problemas [...] gerando uma 'tentação tecnicista."” (SODRÉ, 2002, p. 99-100). Para ele, essa ideologia instala-se não em um horizonte ético, e sim num empresarial, no quadro de uma matriz educacional privatista.

Muitos projetos com tal vertente tecnicista e privatista podem ter consequências enganosas para uma verdadeira política educacional, com interesses mais voltados para projetos de organismos internacionais e para diretrizes mercantilistas internas e externas. Em muitos programas ditos de inclusão digital,

a realidade do computador como produto-fetiche cultural, a real intenção de promover a competitividade empresarial com o apoio à implantação do comércio eletrônico, novas políticas de segurança e outros desígnios estatais eram camuflados pelo discurso oficial no sentido da "alfabetização digital" e educação pública. (SODRÉ, 2002, p. 104).

Para o autor, mais do que transformar as condições reais em que se assentam as velhas estruturas educacionais, tais programas pretendem incluir o maior número possível de pessoas, qualificando-as para o mercado de trabalho pelos “simulacros cibernéticos de 'inclusão de todos na rede'. Em outras palavras, nenhum reflexo do desejo coletivo, tão-só adequação a um cenário tecnoburocrático." (SODRÉ, 2002, p. 104).

Ao enfatizar o tecnicismo instrucional, a educação abre mão da socialização de conhecimentos aliados a valores humanos e ingressa no mercado de bens e serviços. Para Sodré (2002, p. 106, grifos do autor), essa perspectiva está longe de entender que o mais importante em termos de educação "não está nos meios técnicos e seus conteúdos disciplinares (saberes e informações), mas na forma cultural pela qual se incorporam os saberes e se promovem entre eles as conexões pertinentes." Assim, quando programas de inclusão ditos inovadores só enfatizam o acesso aos equipamentos, estão entendendo a escola simplesmente como lugar físico e não como forma cultural.

Fica assim situado um horizonte de referência para refletirmos sobre os desafios da inclusão digital no cenário complexo em que vivemos: a atenção às dimensões culturais - e não meramente técnicas - da relação 
das crianças e dos jovens com as tecnologias; uma compreensão dialética da relação entre escola, mídias e culturas populares; a atenção aos usos locais das mídias e a atenção à possibilidade de que as tensões críticas e criativas de repertórios e linguagens que ali ocorrem sinalizem caminhos de mediação, ainda que circunstanciais, ao abismo digital.

\section{Globalizações e contextos da desigualdade}

O combate à exclusão sempre fez parte da retórica da "sociedade da informação" no contexto de uma sonhada "segunda Renascença" baseada na criatividade, na descoberta científica, no desenvolvimento cultural e na coesão comunitária, como propôs o Fórum Europeu para a Sociedade da Informação. A preocupação com a inclusão perpassa também as recomendações do G7 expressas em diversos encontros internacionais na década de 1990, visando à transição para a "sociedade da informação", e que podem ser assim resumidas: interação global das redes de banda larga; educação transcultural; apoio a bibliotecas, museus e galerias de arte eletrônicas; gestão do ambiente, recursos naturais e saúde; interligação das administrações públicas; inventário global multimedia sobre projetos e estudos para o desenvolvimento da Sociedade Global de Informação.

As experiências que vivemos de lá para cá mostram que de fato o novo paradigma comunicacional e experiencial apresenta espaços de democratização dos meios e das mensagens e permite ao cidadão ultrapassar sua condição de consumidor e/ou espectador para se construir como um sujeito reflexivo e participativo. No entanto, o que assistimos é não só a radicalização das distâncias entre os inforricos e os infopobres, como também a produção de um novo tipo de analfabetismo, o digital.

Há uma considerável disparidade regional na difusão da Internet, visto que os países industrializados, com cerca de $15 \%$ da população do planeta, em 1998 representavam 88\% de seus usuários. Na América Latina, 90\% dos usuários são provindos de grupos de renda mais alta, como observa Castells (2006, p. 433). Para esse autor, “a desigualdade espacial no acesso à Internet é um dos paradoxos mais impressionantes da era da informação em razão da característica supostamente independente do espaço da tecnologia." (CASTELLS, 2006, p. 434). Ele acrescenta que "as novas tecnologias da informação são o instrumento desse redemoinho global 
de acúmulo de riqueza e difusão da pobreza" que atua de modo seletivo, relegando pessoas e territórios inteiros à irrelevância do ponto de vista dos interesses dominantes no capitalismo global informacional. (CASTELLS, 2002, p. 191-192).

Nesse quadro, o Brasil apresenta estatísticas preocupantes: 53\% dos brasileiros nunca usaram um computador e apenas $18 \%$ das residências têm acesso à Internet (SÃO PAULO, 2008). Quanto às crianças em idade escolar (seis a 14 anos) 3\% delas estão fora da escola, correspondendo a 1,5 milhão de crianças (INSTITUTO NACIONAL DE ESTUDOS E PESQUISAS EDUCACIONAIS ANÍSIO TEIXEIRA, 2005); das $162 \mathrm{mil}$ escolas públicas de Ensino Fundamental no Brasil, 129 mil não têm acesso à Internet, 40 mil não tem biblioteca, 25 mil não tem luz elétrica e um mil não tem banheiro. Esses dados reforçam a certeza de que a exclusão digital realmente não pode ser entendida apenas como uma questão de acesso às tecnologias, pois envolve questões bem mais amplas de ordem cultural, política e social.

Ao mesmo tempo em que buscamos a universalização da escolaridade, da leitura e da escrita, vivemos uma época em que, de forma singular, mudanças enormes acontecem dentro de uma mesma geração e não mais de uma geração a outra. Num país de dimensões continentais como o nosso, os problemas também assumem enormes proporções: o desafio da inclusão digital convive com desafios sociais já resolvidos em outras paragens. Daí a necessidade de caminhos e alternativas diante da complexidade de problemas que não são só da educação.

Outra questão que precisamos ter em mente quando falamos de exclusão digital, refere-se ao seu caráter dinâmico, exigindo que países que não estão no núcleo central de produção da tecnologia desenvolvam pelo menos a capacidade de análise defensiva em relação às tendências dos países centrais. No mínimo, "é preciso discutir politicamente a tecnologia e conhecer as opções tecnológicas possíveis para evitar que elas nos sejam apresentadas como inexoráveis e enfiadas por nossa goela abaixo." (SANTOS, 2003, p. 33). Embora seja comum ouvirmos que países pobres podem "queimar certas etapas" do desenvolvimento, absorvendo tecnologias mais avançadas, o desenvolvimento tecnológico é contínuo e movido pela competição. Assim, cada "ultima geração" de aparelhos fica rapidamente ultrapassada e obsoleta e "o caráter altamente dinâmico das 
novas tecnologias é uma barreira constantemente renovada na capacidade de aproximar os países mais pobres dos países mais ricos." (SORJ, 2003, p. 61). Considerando que grande parte da população brasileira não tem acesso físico às novas tecnologias, para que o país possa chegar a participar de modo mais amplo da cultura digital, precisa de políticas públicas que garantam o acesso, o desenvolvimento de softwares e um trabalho de mediação educativo-cultural e de formação para a cidadania através dessas tecnologias.

Diante das preocupantes estatísticas referentes aos índices de alfabetização, precisamos levar em conta o duplo analfabetismo: o funcional e o digital. Seria a informatização completa das escolas a solução para esse problema? A pergunta não tem uma única resposta, mas podemos dizer que a distribuição de computadores nas escolas não será suficiente se não houver uma política de formação dos professores voltada ao enriquecimento cultural e artístico para que o uso dos equipamentos possa ganhar sentido social. Desse duplo analfabetismo decorre um duplo desafio (ou talvez múltiplo, caso consideremos a necessidade de alfabetização em múltiplas linguagens): promover a inclusão digital e a alfabetização digital como políticas públicas, enfrentando a herança do analfabetismo funcional e ao mesmo tempo combatendo o apartheid tecnológico. Avaliar que primeiro se erradica um para depois enfrentar o outro seria um erro primário, como enfatizava Silveira (2001) há vários anos. Sem uma política de investimento na escrita se continuará a produzir a desigualdade na alfabetização digital, dado que esta necessita do domínio da escrita. É preciso notar ainda que as políticas de inclusão digital não podem se limitar à escola e ao ensino formal.

Assim, o acesso às tecnologias de comunicação e o conhecimento técnico dos programas de inclusão digital não são suficientes para construir uma experiência de cidadania, já que eles podem orientar para usos tanto críticos como passivos. É preciso promover condições para o desenvolvimento da autonomia na interação com os meios, de forma a favorecer a formação crítica de cidadãos, não apenas de usuários, incluindo desenvolvimento de critérios de busca. Propiciar a fluência tecnológica significa utilizar de forma crítica as tecnologias da informação e comunicação, interagir com palavras, gráficos, imagens, sons; localizar, selecionar e avaliar criticamente a informação; conhecer e dominar as regras necessárias à prática social da comunicação com suporte nas mídias 
visando a uma aprendizagem significativa, autônoma e contínua, como diz Almeida (2005). Isso oportuniza a produção de conhecimentos necessários à melhoria das condições de vida, em relações e interações comunicativas e de participação na cultura. Essa perspectiva de letramento digital como prática social vai além da aprendizagem do código ou da tecnologia e implica atribuição de significados às informações provindas dos mais diferentes textos, como propõe Almeida (2005). Enfim, é uma perspectiva voltada à produção e representação de conhecimento de si, do outro e do mundo.

\section{Mídia-educação, cidadania e inclusão digital}

As mídias não só asseguram formas de socialização e transmissão simbólica, como também são uma arena central na construção da inteligibilidade do mundo, o que mostra a importância das mediações culturais e pedagógicas ao processo. Nesse sentido, faz-se necessário conceber e apoiar novas formas de apropriação das práticas sociais de leitura e escrita, promovidas sobretudo com o acesso à cultura digital.

Uma das bases teóricas para entender as novas práticas culturais é a abordagem ecológica à mídia-educação (RIVOLTELLA, 2002), entendida como interface entre as diversas áreas do saber, envolvendo ciência, arte, literatura. Poderíamos listar três eixos que sustentam esta abordagem de mídia-educação: cultura (ampliação e possibilidades de diversos repertórios culturais), crítica (capacidade de análise, reflexão e avaliação) e criação (capacidade criativa de expressão, de comunicação e de construção de conhecimentos). A essas três palavras que começam com a "letra C", acrescentamos o C de cidadania, configurando então os "4 C" da mídiaeducação: Cultura, Crítica, Criação e Cidadania, dimensões necessárias a um trabalho transformador na escola (FANTIN, 2006). E isso nos remete à necessidade de pensar a inclusão digital na perspectiva da cidadania.

A mídia-educação é ao mesmo tempo um campo de reflexão teórica sobre as práticas culturais e um fazer educativo, e assim pode constituir-se como um espaço de aproximação significativa entre cultura, educação e cidadania. A partir do caráter instável e da fluidez conceitual do conceito de cidadania, Rivoltella (2005, p. 155) indica algumas dimensões que qualificam a cidadania e o ser cidadão: o direito civil, a cidadania política, a cidadania social e a cidadania cultural. Relacionando tais dimensões da cidadania com 
a mídia-educação, o autor individualiza alguns âmbitos de pesquisa e chega ao que ele chama de "duplo exercício da cidadania", que seria a combinação da cidadania de pertencimento com a cidadania instrumental. De um lado a mídia-educação pode chamar a atenção da sociedade civil e dos poderes políticos aos valores da cidadania e, de outro, por meio de sua especificidade, a mídia-educação contribui para construir essa mesma cidadania. Trata-se de "um duplo exercício de cidadania, ativo e passivo, feito de reivindicação de direitos e de um conjunto de esforços para construí-los." (RIVOLTELLA, 2005, p. 156).

Para Rivoltella, educar para a cidadania envolve: educação inclusiva e baseada no reconhecimento dos direitos universais; aspectos formais e jurídicos da cidadania aos direitos sociais e culturais; educação escolar com trabalho transversal entre as disciplinas, tanto em termos do currículo explícito como do implícito, e uma educação que vise à solidariedade. Implica ademais favorecer a interação como território, desenvolver identidades múltiplas e complexas e promover um sentimento de pertencimento ao contexto local, nacional e global. Essa perspectiva de educar para a cidadania objetiva favorece: a aquisição de conhecimentos (conhecer o mundo e a realidade cultural, social e econômica em que vivemos, as leis, as instituições e seu funcionamento); a aquisição de competências sociais (saber desempenhar o papel de cidadão, cooperar, construir e realizar projetos comuns, assumir responsabilidades, resolver conflitos, intervir em um debate público) e a aquisição de competência ética e relacional (saber ser solidário, estar aberto à diferença etc.).

Ao favorecer este tipo de educação, a escola poderá contribuir com a construção de uma nova forma de mediação cultural, integrando-se aos meios de comunicação a fim de minimizar as assimetrias no plano das capacidades cognitivas e participativas dos indivíduos, como enfatiza Morcellini (2004). Ao transpormos essa ideia para a preocupação com a barreira digital, observamos que nem sempre o termo "inclusão digital" pode ser entendido como o oposto da exclusão, posto que muitas vezes apenas descreve propostas alternativas aos problemas apresentados pela desigualdade social. Com o objetivo de combater as formas de domínio e controle causadas pela desigualdade do acesso às mídias, a bandeira da inclusão digital aparece, sobretudo com o impacto da Internet no mundo, desde a década de 1990. Estar inserido digitalmente passa a ser uma condição 
de cidadania e um direito das pessoas para sua existência plena no mundo da informação e da comunicação.

O debate em torno das formas de inserção da sociedade brasileira neste cenário fica ainda mais candente quando analisamos o desenvolvimento do Mapa da exclusão digital, que em 2003 informava que 85\% da população brasileira estava excluída da sociedade da informação (NÉRI, 2003). Embora o governo federal tenha investido em diferentes programas de inclusão digital, os dados indicam um crescimento desigual entre as regiões do país. Entre 2000 e 2004, o Brasil teve um crescimento de 286,2\% de usuários da Internet, passando a figurar na décima posição da lista dos países com maior número de usuários, com cerca de 19 milhões de internautas, crescimento incomparavelmente maior ao de outros meios de comunicação. ${ }^{2}$ Esse crescimento saltou em 2008 para 67 milhões de usuários, colocando o país no quinto lugar mundial em números absolutos. No entanto a penetração da Internet ocorre de forma desigual, concentrando-se nas classes A e B: a penetração da Internet em relação ao total da população brasileira era de apenas 34,4\% em 2008, o que colocava o país em décimo-quinto lugar em relação ao percentual de internautas entre os 20 países com maior número de usuários, abaixo de países como Turquia (35\%) e Irã (34,9\%). Para efeito de comparação, na vizinha Argentina esse índice era de 49,4\%. ${ }^{3}$ Isso revela que, embora o acesso esteja crescendo, o Brasil tem muito o que andar para reduzir o abismo digital interno.

Considerando que o avanço e a convergência das tecnologias digitais tornam possível, por exemplo, que um telefone celular se constitua em uma central multimídia, sendo ao mesmo tempo uma câmara fotográfica e de vídeo, um computador de bolso com acesso à Internet, um receptor e um emissor de televisão, e que o Brasil é um país aberto a novos desenvolvimentos tecnológicos, esta tendência pode redimensionar a própria discussão sobre o acesso aos equipamentos no contexto da discussão sobre a inclusão digital. A conexão móvel está mudando a percepção do ciberespaço, o que nos deixa cada vez mais "imersos em um nomadismo que articula o espaço de fluxo com o espaço de lugar.” (LEMOS, 2003, p. 2).

Embora de uma perspectiva simplista a receita para transpor a barreira digital seja a disponibilização de tecnologia, vimos que isso é importante, mas não suficiente. Vimos que o termo inclusão digital envolve diferentes significados: embora na maior parte da literatura especializada 
e dos projetos de inclusão esteja implícita a ideia de acesso do ponto de vista tecnológico, entendido sobretudo como um problema técnico, vários estudiosos assinalam que esse parece não ser o melhor caminho para que a inclusão digital possa se transformar em inclusão social. O uso das diferentes linguagens, aliado às possibilidades de interação, certamente pode redimensionar alguns aspectos da exclusão digital no sentido da construção da cidadania e da participação na cultura. Isso favoreceria o diálogo, a negociação de significados, a polifonia, a abertura, a flexibilidade, a crítica e a produção colaborativa.

Esse debate assume grande força nas grandes metrópoles contemporâneas, já que a arquitetura social das cidades reforça a exclusão digital ao não promover habilidades de uso nem proporcionar formas de acesso aos computadores e à Internet, como diz Lemos (2005). Nesta perspectiva, ainda segundo esse autor, os projetos de inclusão digital devem ser elaborados não apenas por analistas de sistemas, administradores e cientistas sociais, mas também por arquitetos e planejadores urbanos. Acrescentamos a importância de que os educadores integrem-se a esses coletivos para ajudar a imaginar formas significativas de mediação entre as possibilidades de uso e as formas de apropriação das tecnologias nos espaços de interação.

Assim, tão importante quanto lutar contra a exclusão social, recuperar o espaço público e promover a apropriação social das novas tecnologias nas cidades por meio de políticas públicas, é estimular uma apropriação crítica e criativa de tais tecnologias. Para isso, considerando que a inclusão pressupõe a exclusão e sua consequente superação, é fundamental perguntar: por que incluir? O que significa incluir? A inclusão digital é direito ou necessidade? Em países periféricos a inclusão significa uma possibilidade de desenvolvimento ou um risco de colonização, diluição e apagamento? Se o problema da inclusão também é cultural, o que significa a inclusão enquanto acesso do ponto de vista tecnológico? Que direitos o acesso tecnológico ao computador promove se não for acompanhado de uma alfabetização nas múltiplas linguagens? Acessar o computador sem estar alfabetizado é promover seu uso e os direitos nele envolvidos? Enfim, será a inclusão sempre positiva ou boa a priori? Se hoje a ênfase da literatura internacional sobre a barreira digital recai sobre os aspectos técnicos do 
problema, as perguntas que formulamos acima acentuam sobretudo o problema da inclusão cultural.

Observamos que hoje o termo inclusão, num certo debate público, parece ter virado um rótulo politicamente correto consensual, imune à reflexão e à discussão. O princípio de que a sociedade deva estar incluída na era da informação é aceito sem questionamento e a pergunta "o que vem a ser um sujeito incluído e o que ele fará com essa nova ferramenta?" parece pouco importar. Sem garantias de empregabilidade e diante da velocidade da superação tecnológica, o discurso da inclusão digital parece feito sob medida para contentar empresas, organizações e tecnólogos que o vendem como mais uma novidade no mercado, na linha do que diz Lemos (2005, p. 6). Nesse contexto, incluir parece significar oferecer condições materiais (destreza e acesso à Internet) para o manuseio das tecnologias. Mais do que desenvolver processos cognitivos críticos e questionadores, incluir, nessa perspectiva, parece ser meramente adaptar procedimentos a técnicas correntes.

Se a exemplo do que está implícito na maioria dos projetos de inclusão, ${ }^{4}$ incluir significa dar acesso a computadores proprietários com softwares primitivos e treinar mecanicamente para o uso eficiente no trabalho, por que razão a sociedade deveria ser incluída? A quê e a quem serve essa inclusão? Em sociedades como a nossa, onde direitos básicos como saúde, educação, moradia e segurança ainda não estão assegurados, Lemos (2005) pergunta: é possível avaliar a inclusão social pelo número de computadores, internautas e outras estatísticas do gênero? E destaca que nessa perspectiva incluir parece ser basicamente adaptar, moldar. A inclusão, porém, precisaria se distinguir da simples adaptação à lógica tecnocrática. Isso, se concordarmos com Freire (2000, p. 90) em que "é na inserção no mundo e não na adaptação a ele que nos tornamos seres históricos e éticos, capazes de optar, de decidir, de romper."

A inclusão digital digna desse nome envolve dimensões sociais, culturais, tecnológicas e intelectuais, a fim de favorecer formas de pertencimento e assegurar a participação efetiva das pessoas na cultura. Assim, as políticas de inclusão digital também devem incentivar a desconcentração do poder, a autonomia local, regional e nacional, opondose à subordinação aos monopólios e o aprisionamento às redes privadas, como observa Silveira (2003). 
Outra alternativa para intervir no problema de forma crítica é o movimento pelo software livre: “O movimento de software livre é expressão autêntica desse potencial da rede e o grande modelo para consolidação de soluções compartilhadas diante de questões complexas, a partir da interação multiétnica, multinacional e multicultural.” (SILVEIRA, 2003, p. 38). Entendendo o modelo do software livre como uma opção viável do ponto de vista econômico, e inovadora e estável enquanto tecnologia, "seria extremamente viável utilizarmos mais amplamente o software livre, pois além de não enviarmos royalties poderíamos nos firmar como grande produtor e distribuidor de soluções em código aberto." (SILVEIRA, 2003, p. 40). Esse uso do software livre pode exemplificar uma das facetas da imaginação de que fala Santos (2002, p. 46):

é através da imaginação que os cidadãos são disciplinados e controlados pelos Estados, mercados e outros interesses dominantes, mas é também da imaginação que os cidadãos desenvolvem sistemas coletivos de dissidência e novos grafismos da vida coletiva.

\section{Uma perspectiva cultural de inclusão digital}

Se a inclusão digital não deve se configurar simplesmente como acesso a um modelo de ensino técnico onde os alunos aprendam a usar softwares e a navegar na Internet, uma perspectiva ecológica da mídiaeducação (RIVOLTELLA, 2000) pode contribuir para outra perspectiva de inclusão digital.

O paradigma ecológico da mídia-educação apresenta uma concepção integrada, que se refere a fazer educação usando todos os meios e tecnologias disponíveis: computador, Internet, fotografia, cinema, vídeo, livro, CD, articulando as propostas educativas com as exigências do ambiente comunicativo a partir de cada inovação tecnológica, integrando-as entre si. Por mais que hoje o computador, a Internet e a rede sejam fundamentais e até mesmo considerados condição de inserção e participação social, a mídiaeducação não se limita a eles, sendo fundamental analisar as necessidades de cada grupo, projeto e contexto. Nessa perspectiva, o objetivo do trabalho educativo na escola não é apenas o uso da sala informatizada ou do 
laboratório multimídia e sim que a criança e o jovem atuem nesses e noutros espaços, estabelecendo interações e construindo relações e significações. A mediação deve ser pensada também como forma de assegurar e/ou recuperar a corporeidade - o gesto, a voz, a postura, o movimento, o olhar - e a relação com a natureza como dimensões fundamentais de construção de sentidos.

As diferentes formas de cidadania - civil, política, social e cultural - são desafiadas pelos novos meios na sociedade contemporânea, requerendo novas formas de pensar a educação e enfrentar a desigualdade social. Em relação à mídia-educação, novas ênfases podem ser verificadas: uma que aponta para uma "new media education"; outra que aponta para uma "new media education", conforme destaca Rivoltella (2006). A primeira perspectiva acentua que os novos meios impõem novas exigências educativas, e que crianças e jovens precisam de outras formas de educação (medialiteracy, ciberliteracy). A segunda perspectiva destaca que com a mudança no papel social dos meios na nossa sociedade, o paradigma da mídia-educação também precisa mudar, em uma perspectiva integradora e não excludente que procure respostas aos desafios de uma sociedade em que os meios não são coadjuvantes e sim protagonistas. Uma nova mídia-educação atenta a esses desafios teria que ir além do funcionalismo e do criticismo, aproximando-se de uma perspectiva culturalista. Para Rivoltella (2006), tal hipótese partiria das tecnologias de produção e dos signos para chegar às tecnologias de si em um cenário em que a mídiaeducação seria entendida como educação de modo amplo e todo educador teria uma postura mídia-educativa, com a cidadania como uma de suas dimensões centrais.

No campo da mídia-educação, o enfrentamento à barreira digital diz respeito à educação para a cidadania no seu duplo aspecto: a cidadania de pertencimento e a cidadania instrumental, o que implica propostas de mediação que assegurem a possibilidade de uma apropriação crítica e criativa das tecnologias, visando à autoria dos sujeitos, sua inserção e participação na cultura.

No âmbito da educação, as possibilidades de participação cidadã de crianças e jovens assumem especial relevância. Seria possível imaginar que através de uma mediação educativa intencional as crianças e os jovens, interagindo com as tecnologias e construindo suas tecnologias de 
si conseguiriam transcender os limites colocados pelo individualismo e construir outras dimensões de participação?

Se é verdade que no processo de cruzamento e recombinação entre culturas globalizadas e locais ocorre uma reinterpretação ativa (GARCIA CANCLINI, 1998; BROUGÉRE, 2004), esta não se dá de modo absoluto. Podemos nos perguntar: quais as possibilidades de autonomia das crianças e dos jovens nessa reinterpretação, num contexto em que a globalização econômica e a mundialização da cultura operam de modo complexo e contraditório no estatuto da infância (PINTO, 1997, BUCKINGHAM, 2007)? Tensões entre heterogeneização das condições de existência de vida e pressões uniformizadoras contribuem para a formação de identidades sociais fragmentárias e cambiantes, num espaço social contemporâneo de (re)institucionalização da infância que também pode abrir-se a paradigmas alternativos.

Neste quadro, a escola evidentemente assume papel crucial, não podendo se manter divorciada do movimento de construção dos direitos das crianças, incluindo o direito à cidadania digital. Como serviço público, ela precisa promover a vivência de todas as dimensões da pessoa no presente; não apenas como lugar de preparação para que um dia o sujeito seja cidadão, mas como um lugar onde na infância a cidadania seja uma realidade.

Os programas de inclusão digital terão que levar em conta, assim, as especificidades da memória, das tradições, dos objetivos, valores, temores e esperanças dos jovens em cada cultura. Projetos desenhados de cima para baixo ou do "centro" para a "periferia" nos quais não haja espaço para a emergência de diferentes respostas a essas realidades subjetivas diversas, sem dúvida alcançarão resultados limitados do ponto de vista da participação e da cidadania. Também nesse sentido, uma inclusão digital mais plena se configura necessariamente como inclusão cultural.

Vemo-nos hoje à beira de diversos abismos - entre culturas, entre classes com acesso desigual aos bens materiais e imateriais e entre gerações. Desse lugar, percebemos a necessidade de aguçar nossos recursos de compreensão e de investir na transformação das linguagens, conteúdos e contextos de recepção, bem como no aprimoramento da capacidade de compreender as necessidades e desejos dos mais jovens. Ao mesmo tempo, as novas formas culturais podem também se constituir em suportes ou pontes que permitam cruzar aqueles desfiladeiros. Por um lado, precisamos 
nos adaptar a novos modos de ver, ler, pensar, aprender, interagir e intervir na realidade; mas ao mesmo tempo precisamos seguir reivindicando a presença da cultura oral, da escrita e da audiovisual no espaço escolar.

Poderíamos imaginar que a educação mediada pela tecnologia assemelhe-se a um jogo em que cada vez mais as máquinas se transformam em aparatos para recuperarmos a dimensão lúdica na produção do conhecimento. Assim, os adultos podem aprender com os jovens a dimensão lúdica no uso das tecnologias digitais em que jogar com/contra os aparelhos pode ser um modo de resgatar a liberdade num mundo programado pela tecnologia, como diz Flusser (1998). Por outro lado, crianças e jovens podem aprender com os adultos que a história em processo e a herança cultural são os fundamentos da experiência atual.

\section{Participação na cultura como mediação à barreira digital}

Quando apostamos no papel destacado da participação cultural em uma mídia-educação preocupada com a inclusão, precisamos considerar que o conceito de participação é polissêmico. Em sua origem latina, a palavra participatio refere-se a tomar parte na ação. Para ter parte na ação é necessário ter acesso ao agir e às decisões que orientam esse agir. Assim, executar uma ação não significa necessariamente ter parte ou responsabilidade sobre a ação. Só será sujeito da ação quem decidir sobre ela. O sentido da palavra em grego tangencia várias situações entre a vida privada e a vida pública, o que nos leva de volta ao conceito de cidadania. E este é um dos sentidos em que pensamos a participação: como ação do sujeito, como autonomia e autoria no exercício político da cidadania.

O termo participação remete ainda à diversidade, à pluralidade e aos temas da liberdade. Palavra forte e politizada, é matizada por valores e interesses diversos, estando por isso sujeita a diferentes usos ou simplificações. Afinal, sempre que alguém participa de algo, o faz em relação a determinados desejos ou interesses. Num exercício de exploração conceitual, podemos nos perguntar, por exemplo: qual o oposto de participação? Será simplesmente a "não participação"? Será a "apatia", a "indiferença", a "exclusão"?

Pensando a participação também pelo viés da marginalidade, como estamos fazendo, não podemos esquecer que em sociedades heterônomas 
como a nossa o excluído está sempre de alguma forma incluído, no mínimo porque aquilo que está à margem preocupa. Assim, o centro inclui os de fora, pois estes são sempre referências em seus projetos, estejam presentes ou ausentes, participando e integrando o mesmo imaginário compartilhado, ou seja, a mesma cultura. Nesse sentido, o não participante é, paradoxalmente, partícipe. O "de fora" está "dentro".

A reconfiguração centro/periferia é central para se compreender as dinâmicas de participação cultural no Brasil de hoje. A produção cultural e artística apoiada em tecnologias digitais nas comunidades empobrecidas das metrópoles brasileiras assumiu nos anos recentes crescente importância social, estética e econômica. De acordo com o antropólogo Vianna (2006), "a novidade mais importante da cultura brasileira na última década foi o aparecimento da voz direta da periferia falando alto em todos os lugares do país." Essa voz está claramente ligada às possibilidades tecnológicas de sua amplificação e reprodução, que a tornam mais acessível às comunidades e coletivos artísticos, capazes de ouvir sua própria música, filmar suas histórias, assistir sua dança.

Analista da cultura brasileira contemporânea, Vianna é um entusiasta dos centros de acesso comunitário e gratuito à Internet: "os telecentros", diz ele,

podem tanto produzir o orgulho comunitário e cidadão nas periferias quanto conectar todas essas periferias entre si e com o mundo, não deixando que suas conquistas criativas sejam cooptadas por sistemas político-culturais de "fora" ou organizações criminosas de "dentro" que querem apenas tornar as periferias mais periféricas. (VIANNA, 2004).

Ele descreve como os telecentros da cidade de São Paulo vivem lotados de jovens, que ali perdem o medo do computador, "tratando-o como brinquedo" e, à medida que ficam íntimos das máquinas, passam a programá-las. Como esses telecentros operam com software livre a programação é incentivada. "As máquinas não guardam segredos, seus códigos são abertos, e quem quiser pode investigar mesmo o núcleo de seu sistema operacional", explica Vianna (2004), ao relatar um exemplo representativo da conexão entre a periferia de São Paulo e o movimento 
político, cultural e econômico por ele considerado o mais importante hoje no mundo: "Qualquer outro movimento político, da antiglobalização ao dos sem-terra, se revela ineficiente diante das conquistas do software livre." (VIANNA, 2004). Para ele, esse movimento tem um significado revolucionário, apesar de acontecer quase em surdina.

Podemos, é claro, relativizar a dimensão atribuída ao movimento pró-software livre por Vianna ou, no mínimo, ficarmos à espera de maiores evidências quanto a seus resultados. No entanto, não podemos desconsiderar que o que o autor chama de "uma revolução" baseia-se de fato em "um regime colaborativo e descentralizado, sem um partido político no comando, mas com pedaços de código em computadores diferentes espalhados pelo planeta, comandados por gente que trabalha não para ficar rica, mas querendo o bem comum." (VIANNA, 2004). Sem dúvida, isso é relevante para a perspectiva da inclusão. Destaca-se ainda na produção fervilhante da juventude nos telecentros brasileiros seu caráter público e visível, uma alternativa ao que Graham (apud LEMOS, 2005, p. 3) indicou como um dos obstáculos para a democratização das tecnologias que seria seu uso de forma invisível e individual.

O entusiasmo pelos telecentros não é uma unanimidade no país, embora eles façam parte da maioria dos projetos de inclusão digital. Lemos (2003, p. 2), por exemplo, argumenta que embora os telecentros sejam vistos como a "nova panaceia da inclusão" não passam de um paliativo para o problema do acesso e da formação, pois a tendência é a disseminação generalizada da rede por todas as áreas (escolas, praças, cidades inteiras) "onde cada cidadão terá, querendo ou não ser incluído, que lidar com máquinas de comunicação conectadas.” Qualquer que seja a forma política de implantação de tecnologias nas comunidades, contudo, o aspecto que queremos destacar aqui é a possibilidade de criação artística e cultural que elas têm de fato viabilizado.

É neste sentido que a cultura digital pode ser entendida como um conceito novo, pois "parte da ideia de que a revolução das tecnologias digitais é, em essência, cultural”, como diz Gil (2004). Isso evidencia o quanto o uso das tecnologias digitais muda os comportamentos, permitindo que a tecnologia deixe de ser considerada somente como ferramenta e seja necessariamente entendida em seus aspectos de identidade e produção de subjetividade. Nessa perspectiva, o uso pleno da Internet e do software livre, por exemplo, cria 
possibilidades incalculáveis de democratizar os acessos à informação e ao conhecimento, ampliar os potenciais dos bens e serviços culturais, amplificar os valores que formam o nosso repertório comum e, portanto, a nossa cultura, e potencializar também a produção cultural, criando inclusive novas formas de arte, como sugere ainda Gil (2004). Isso ocorre porque a tecnologia, como instrumento de inclusão social, adquire novo contorno, "não só como incorporação ao mercado, mas como incorporação à cidadania e ao mercado" quando assegura o acesso à informação e o barateamento dos custos dos meios de produção multimídia, que podem ampliar o potencial criativo do cidadão. Se considerarmos que este cidadão é a um só tempo consumidor, emissor, receptor e produtor de saber e informação, que possui autonomia relativa e que está conectado em redes, as possibilidades de sua participação na cultura podem ser ampliadas.

No campo da educação, a participação está relacionada à necessidade de descentralização e democratização da gestão escolar, aos direitos sociais das crianças, adolescentes e jovens e a determinadas concepções de ensinoaprendizagem, tornando-se um conceito central nos últimos anos a partir da perspectiva de educação para a cidadania.

\section{Para além da inclusão digital}

Levando em conta as necessárias aproximações entre as culturas e práticas cotidianas de crianças e jovens em diferentes espaços da prática social, no decorrer do texto destacamos diversas lacunas que não são preenchidas apenas com o acesso às tecnologias na escola. Ainda que o entusiasmo que acompanha o investimento em tecnologias seja necessário, é preciso refletir sobre o sentido do que se pode fazer com essas tecnologias dentro e fora da escola. Uma mídia-educação associada às mediações culturais nos parece fundamental enquanto crítica e alternativa ao uso puramente funcional das tecnologias digitais. Se hoje a ênfase de muitos programas de inclusão digital reside nas competências instrumentais, estas precisam ser consideradas apenas um ponto de partida para o desenvolvimento de formas e linguagens nas quais as pessoas possam relacionar-se crítica e criativamente com o mundo ao seu redor.

As reflexões no decorrer do texto procuraram enfatizar que se a economia da sociedade da informação é globalizada, os indivíduos 
continuam a ter uma existência local, o que reafirma o abismo entre globalidade da riqueza e do poder e as experiências locais. No entanto, procuramos ressaltar que esse e outros abismos podem ser mediados. Propomos a imagem da mediação educativa na perspectiva cultural como possibilidade de navegação não em um rio - que separa e une de que falamos no início do texto, mas no grande mar digital. Como na canção Pela internet, de Gilberto Gil, ${ }^{5}$ trata-se de descobrir "com quantos gigabytes se faz uma jangada, um barco que veleje nesse infomar" (GIL, 2004).

Esperamos ter sugerido algumas pistas nesta direção, rumo a um entendimento da inclusão digital enquanto construção de cidadania em que a mídia-educação assegure uma real participação de crianças, jovens e adultos na cultura. Mesmo sem obviamente esgotar o assunto, cuja complexidade se renova a cada dia, buscamos ter contribuído para a discussão num tom que, apesar de crítico, é também esperançoso.

\section{Notas}

1 Bazalgette (2005) propôs os “3 C" - cultura, crítica e criação - como três aspectos essenciais da mídia-educação.

2 Internet World Stats. Disponível em: < http//: www.internetwordlstats. com.>. Acesso: 4 jan. 2008.

3 Internet World Stats. Disponível em: < http//: < www.internetworldstats. com >. Acesso em: 2 jun. 2009.

4 Analisando diversos projetos de inclusão digital, Lemos (2005) afirma que a maioria deles privilegia a dimensão técnica em detrimento da social, cultural e intelectual.

5 GIL, Gilberto. Pela Internet. Álbum Quanta. Warner Music Brasil, 1997.

\section{Referências}

ALMEIDA, M. Elisabeth. Letramento digital e hipertexto: contribuições à educação. In: PELLANDA, Nize; SCHLÜNZEN, Elisa; 
SCHLÜNZEN, Klaus (Org.). Inclusão digital: tecendo redes afetivas/ cognitivas. Rio de Janeiro: DP\&A, 2005.

ANDRADE, Oswald. Manifesto Antropofágico. Disponível em: <http:// www.brasilcultura.com.br/literatura/manifesto-antropofago/>. Acesso em: 8 jun. 2009.

AZEVEDO, Ricardo. Formação de leitores, cultura popular e contexto brasileiro. Jornal da USP, São Paulo, ano XXI, n.749, jan. 2006.

BAZALGET'TE, Cary. Media education in Inghilterra: incontro con Cary Bazalgette nel suo ufficio. Boletim InterMED, Roma, v. 10, n. 3, p. 2-4, 2005.

BROUGÉRE, Gilles. Brinquedos e Cia. São Paulo: Cortez, 2004.

BUCKINGHAM, David. Crescer na era das mídias eletrônicas. São Paulo: Loyola, 2007.

CASTELLS, Manuel: A sociedade em rede. São Paulo: Paz e Terra, 2006.

FANTIN, Monica: Midia-educação: conceitos, experiências, diálogos BrasilItália. Florianópolis: Cidade Futura, 2006.

FANTIN, Monica; GIRARDELLO, Gilka. Digital literacy and cultural mediations to the digital divide. In: RIVOLTELLA, Pier Cesare. Digital literacy: tools and methodologies for information society. Hershey, New York: IGI Publishing, 2008.

FLUSSER, Villém. Ensaio sobre a fotografia: para uma filosofia da técnica. Lisboa: Relógio d'Água, 1998.

FREIRE, Paulo. Pedagogia da indignação: cartas pedagógicas e outros escritos. São Paulo: Editora Unesp, 2000.

GARCÍA CANCLINI, Nestor. Culturas híbridas: estratégias para entrar e sair da modernidade. São Paulo: Editora da USP, 1998.

GIL, Gilberto. Aula Magna na USP: cultura digital e desenvolvimento. São Paulo: USP, 2004. Disponível em: <http://www.cultura.gov.br/ noticias $/$ discursos $/$ index.php? $\mathrm{p}=833 \&$ more $=1>$. Acesso em: 28 nov. 2006. 


\section{INSTITUTO NACIONAL DE ESTUDOS E PESQUISAS EDUCACIONAIS ANÍSIO TEIXEIRA. Prova Brasil 2005. Brasília, 2005.}

LEMOS, André. Dogmas da inclusão digital. Correio Bražliense, Brasília, 13 dez. 2003. Caderno Pensar. Disponível em: <http:www.facom.ufba. br/ciberpesquisa/andrelemos>. Acesso em: 20 nov. 2006.

LEMOS, André; COSTA, Leonardo. Um modelo de inclusão digital: o caso da cidade de Salvador. Revista de Economia Política de las Tecnologias de la Información y Comunicación, Sergipe, v. 8, n. 6, sep./dic. 2005. Disponível em: <http:wwweptic.com.br/português/Revista $\% 20$ EPTIC $\% 20$ VIII\%20-\%20AndreLemos-LeonardoCosta.pdf>. Acesso em: 20 nov. 2006.

MARTÍN-BARBERO, Jesús. Ofício de cartógrafo: travessias latinoamericanas da comunicação na cultura. São Paulo: Loyola, 2004. MORCELLINI, Mario (Org.). La Scuola della Modernità: per un manifestdo della media education. Milano: Franco Angeli, 2004.

NERI, Marcelo. Mapa da exclusão digital. Rio de Janeiro: FGV/IBRE, CPS, 2003.

PINTO, Manuel. A infância como construção social. In: PINTO Manuel e SARMENTO, Manuel. As crianças: contextos e identidades. Minho, Centro de Estudos da Criança, 1997.

RIVOLTELLA, Pier Cesare. Media education: modelli, esperienze, profilo disciplinare. Roma: Carocci, 2002.

- Media education: fondamenti didattici e prospettive di ricerca.

Brescia: Editrice La Scuola, 2005.

- Screen generation. gli adolescente e le prospettive dell'educazione nell'età dei media digitali. Milano: Vita \& Pensiero, 2006.

SANTOS, Boaventura de Souza. A globalização e as ciências sociais. São Paulo: Cortez, 2002.

SANTOS, Laymert Garcia. A informação após a virada cibernética. In: SANTOS, Laymert et al. Revolução tecnológica, internet e socialismo. São Paulo: Fundação Perseu Abramo, 2003. 
SÃO PAULO (Estado). Comitê Gestor da Internet no Brasil. Pesquisa sobre o uso das tecnologias da informação e da comunicação no Brasil 2008. São Paulo, 2008.

SILVEIRA, Sérgio. A exclusão digital: a miséria na era da informação. São Paulo: Editora Fundação Perseu Abramo, 2001.

. Inclusão digital, software livre e globalização contrahegemônica. In: SILVEIRA, Sérgio; CASSINO, João (Org.). Software livre e inclusão digital. São Paulo: Conrad Editora do Brasil, 2003.

SODRÉ, Muniz. Antropológica do espelho: uma teoria da comunicação linear em rede. Petrópolis: Vozes, 2002.

SORJ, Bernardo.brasil@povo.com: a luta contra a desigualdade na sociedade da informação. Rio de Janeiro: Jorge Zahar; Brasília: UNESCO, 2003.

SCHWARTZ, Gilson. Exclusão digital entra na agenda econômica mundial. Folha de S. Paulo, São Paulo, 18 janeiro 2000. . Analfabetismo digital. Revista Educação, São Paulo. Disponível em: <http://revistaeducacao.uol.com.br/apresenta2.php?pag $\mathrm{id}=121 \&$ edicao $=248>$. Acesso em: 27 nov. 2006.

VIANNA, Hermano. A disseminação silenciosa do software livre. Folha de S. Paulo, São Paulo, 18 abr. 2004. Caderno Mais.

. Central da Periferia: texto de divulgação. In: OVERMUNDO. Rio de Janeiro, 16 out. 2006. Disponível em: <http://www.overmundo. com.br>. Acesso em: 18 maio 2009. 


\section{Facing the digital abyss: \\ Media-Education and cultural mediations}

\begin{abstract}
:
This article discusses digital inclusion from the perspective of education and culture, highlighting the ways the question is presented in Brazil, but understanding that they are not exclusive to this context. Given the complex challenges for digital conclusion in the context of globalization, the article emphasizes the importance that children and youth have real opportunities to use new technologies and languages, understanding that inclusion means much more than access to technologies, and is one of the fronts in the struggle against inequality. The authors propose that the understanding of the digital barrier be enriched through the valorization of cultural mediations. The paper discusses the possibilities for a culturalist perspective of media-education and promotes digital inclusion that is an experience of citizenship, belonging and critical and creative participation in the culture.
\end{abstract}

Key words: Digital Inclusion. Media. Citizenship. Education technological Innovations.

\section{La educación mediática y mediaciones culturales frente al abismo digital}

\section{Resumen:}

El presente artículo discute la inclusión digital en la perspectiva de la educación y la cultura, destacando las especificidades de cómo se presenta en Brasil, pero también entendiendo que ellas no son exclusivas de ese contexto. Delante de los complejos desafíos de la inclusión digital en el contexto de la globalización, el artículo enfatiza la importancia que los niños, niñas y los jóvenes puedan apropiarse de la tecnología y del lenguaje de manera significativa, configurándose uno de los frentes de lucha contra la desigualdad. Las autoras proponen que el entendimiento de la barrera digital sea enriquecido con la valorización de las mediaciones culturales. En ese sentido, discuten la posibilidad de una perspectiva culturalista de la educación mediática para promover una inclusión digital que sea una experiencia de ciudadanía, de pertenencia y participación crítica en la cultura.

Palabras-clave: Inclusión digital. Medios. Ciudadanía. Educación. Innovaciones Tecnológicas. 


\section{Monica Fantin}

Rua Prof. Walter Bona Castelan, 434

CEP: 88037-300 - Florianópolis - SC

Tel:(48) 3233 2759/8412 1285

E-mail:mfantin@terra.com.br

\section{Gilka Girardello}

C.P. 10.192

CEP: 88062-970 - Florianópolis - SC

Fone: (48)3232-8953/9922-8963

E-mail: gilka@floripa.com.br

Recebido em: 26/3/2009

Aprovado em: 15/5/2009 